\title{
Chocolate packaging cues and first moment of truth: An exploratory study on young consumers' mind
}

\author{
Suraj Kushe Shekhar* and P.T. Raveendran
}

Department of Management Studies, Kannur University, Thalassery campus, Palayad Post, Kannur, Kerala-670661, India

\begin{tabular}{l}
\hline C H R O N I C L E \\
\hline Article history: \\
Received February 12, 2013 \\
Received in revised format \\
10 May 2013 \\
Accepted 12 May 2013 \\
Available online \\
May 28 2013 \\
\hline Keywords: \\
Chocolate \\
International brand \\
National brand \\
Packaging
\end{tabular}
\begin{abstract}
A B S T R A C T
Packaging is often called as the fifth P of the marketing mix. Chocolate is a product which is loved to be consumed irrespective of any age group. Consumers were asked to imagine that a new chocolate bar has been launched in the market and were yet to sense (sight or taste) it or a chocolate bar which was already launched in the market and were yet to sense (sight or taste) it .The present study explored different chocolate packaging cues that could possibly influence the purchase decision of young consumers in such a scenario. Descriptive research with convenient sampling elicited 240 responses across the age group lying between 11 to 27 years. Results showed that an attractive package design was of paramount significance in first purchase of chocolate bars. The important factors which affected the buying decision were 'Information' and 'Visual aesthetics'. However it was found that chocolate packaging had less influence on subsequent purchase of chocolate bars. It was also inferred that an attractive package along with a strong advertising campaign could bring prospective sales for a newly launched chocolate bar. The study also discussed the influence of chocolate packaging for national and international brands across various demographic variables.
\end{abstract}

\section{Introduction}

Packaging is described as the science, art, and technology of enclosing or protecting products for distribution, storage, sale, and use (Soroka, 2002). Stewart (1995) pointed out that the basic function of food packaging was to preserve product integrity by protecting the food against possible damage from climate, bacteriological and transit hazards. However, the first to term packs as the 'silent salesman' was Pilditch who opined that the pack must animate at the point of purchase, in order to represent the salesman (as cited in Vazquez et al., 2003). The 'first moment of truth' is a metaphor used for describing customer decision making at the point of purchase (Lo“ fgren, 2008).New product packaging persuade consumer buying behaviour and is an important facet of market success (Sharma, 2008). According to Doherty and Tranchell (2007), the world loves chocolate.They opined that nine *Corresponding author. Tel: +91-497-2765500,+91-9446533755

E-mail addresses: surajkushe@gmail.com (S.K. Shekhar) 
out of ten people liked chocolates and the tenth person always lied. They even mentioned that chocolate could make everyone smile even bankers. Patwardhan et al. (2010) made an attempt to find the secondary factors affecting consumer's buying habits, with focus on soaps and chocolates. Packaging in the chocolate industry is critical. Today packages are designed to go with different occasions, demand to different social classes and differentiate between different brands. Based on the results from relevant previous research studies, this paper makes an attempt to identify the influence of chocolate packaging cues on young consumers.

\section{Review of related literature}

Packaging is an important factor in consumer judgment making process. Silayoi and Speece (2004) opined that five main packaging elements positively affect consumer purchase process. They separated those into two categories: visual (size, graphic and shape) and informational (information and technologies) elements. Bassin (1988) opined that packaging could add value through brand identification, serve as advertisement at the point-of-sale, help the consumer transport the product, improve at-home storage, add value by providing task assistance etc.

Nancarrow et al. (1998) illustrated that a thorough understanding of consumer models, mental processes and appropriate usage of marketing research techniques could assist the design of food packaging and label copy thereby providing any company with a competitive advantage. The authors concluded that a thorough understanding of the consumer was central to the success of a pack design. Rettie and Brewer (2000) described the idea of brain laterality in processing the visual and verbal information under situations of fast perception with respect to packages. The authors positioned verbal and visual cues on different sides of a pack and tested the recall of those elements. It was found that to maximize recall; words had to be placed on the right-hand sides of packs and pictures on the left. The results confirmed the irregularity of perception of elements of packaging.

Bone and France (2001) found out that the graphical element of the label could largely influence attribute beliefs and purchase intentions even when the verbal element of the package was held constant and provided precise information about product attributes. They also suggested that graphical information could even be confusing and affect the consumer's buying behaviour.

Underwood et al. (2001) suggested a theoretical framework to understand the communicative effects of a product imagery or picture on packages. The experiential results showed that packaging pictures increased consumers' attention to the brand.

Underwood (2003) proposed that packaging influenced the brand and self identity via mediated (through exposure to mass-communication culture and mass media products) and lived in experience (interaction with the brand, normally resulting from purchase and usage). Silayoi and Speece (2004) discussed consumer behaviour towards packed food products and how packaging elements could affect buying decisions based on the impact of time pressure and involvement level. Ampuero and Vila (2006) discussed shopper's perception on product packaging design and the desired positioning in the minds of the consumers. The study showed high degree of correlation between packaging designs and positioning perceptions in the minds of the consumers'. Barber et al. (2006) investigated those attributes of wine packaging that were appealing to shoppers and found out that compared to males; front label image, logo and picture were momentous to females as was label colour. Raghubir and Greenleaf (2006) discussed that the ratio of the sides of a rectangular product or package could encourage purchase intentions and preferences and was also associated to marketplace demand. Sehrawet and Kundu (2007) in their study compared the buying behaviour of rural and urban consumers in India with special reference to product packaging. The study showed that the rural and urban consumers varied considerably on various aspects of packaging. Rural consumers felt that packaging was more helpful in purchasing than their urban counterparts. Rural consumers also believed that better packages usually contained better products. 
L fgren et al. (2008) explored a better understanding of how customers perceived different aspects of the package in the first and second moments of truth. Results showed that there were notable differences of the impacts of customer satisfaction on loyalty in the first moment of truth compared to the second moment of truth. Estiri et al. (2010) analyzed the effects of packaging elements on consumer behaviour in three stages of decision making process: pre-purchase, purchase and post purchase. It was observed that the informational elements of food packages were considered as the most important element while visual element of packaging attracted least attention in all the three stages of purchase decisions. Serralvo et al. (2010) discussed the visual characteristics of food packages and their potential influence on the growth of consumer attitudes composed by affective, cognitive, and behaviour components. Aziz et al. (2011) examined the significance of packaging on consumer purchase decision making process for three brands of pharmaceutical products. The article examined the influence of promotional, informational and functional aspects of packaging on consumers' buying behaviour. Venter et al. (2011) explored a sample of South African shoppers' perceptions of food packaging and how these perceptions were shaped through the perceptual process. An attractive packaging for the chocolates forces consumers to buy the chocolates. Even though a few may not approve it psychologically, such good packages undoubtedly improves the mental image of the product. Packaging tends to increase the value and worth of the chocolate and can even reflect the quality of the contents inside the package (Giyahi, 2012). A study conducted by Vreeland (2000) indicated that chocolate prices influenced consumer behaviour. Demetris and Claudio (2001) reported a study related to Cadbury Dairy Milk; which revealed that 'chocolate ingredients' and 'chocolate cost' were among the major consideration factors for consumers, before buying chocolate. The present study explored different chocolate packaging cues that could possibly influence the purchase decision of young consumers. Only chocolate bars were included in the study. Assorted chocolates, candies and gums were excluded.

\section{Objectives of the study}

1. To identify the important packaging cues (factors) influencing young consumers' perception when they planned to purchase or purchased newly launched branded chocolate bars.

2. To identify the influence of chocolate packaging cues across various age groups.

3. To identify the influence of chocolate packaging across two genders; males and females

\section{Hypotheses}

1. There was no significant difference regarding the influence of chocolate packaging cues (factors) as far as genders were concerned.

2. There was no significant difference regarding the influence of chocolate packaging cues as far as different age groups of the respondents were concerned.

3. The influence of packaging for repeated purchase of chocolate bars was independent of the gender of the respondents.

4. There was no significant difference regarding the influence of packaging in the purchase of chocolate bars of national brands as far as qualifications were concerned.

5. There was no significant difference regarding the influence of packaging in the purchase of chocolate bars of national brands as far as age groups were concerned.

6. There was no significant difference regarding the influence of packaging in the purchase of chocolate bars of international brands as far as qualifications were concerned.

7. There was no significant difference regarding the influence of packaging in the purchase of chocolate bars of international brands as far as age groups were concerned.

\section{Methodology}

The study was designed as a multiple cross sectional descriptive type of research (Malhotra, 2006). The study described the perception of three different groups of chocolate consumers' namely i) 
secondary/higher secondary students, ii) graduates and iii) postgraduates towards chocolate packaging. Convenient sampling was used as the sampling technique and a total of 240 responses were elicited. Primary data was used in the research and a survey method of data collection technique was carried out. Survey was carried out in two schools and four colleges in Kannur district of Kerala State. A well structured pre-tested questionnaire was used as the data collection instrument. Pretesting of the questionnaire was done among a small group of students from a college to modify/eliminate inconsistency and lack of clarity in certain questions. The final survey was administered in the following way.

The researcher prefixed an appointment to meet the students of various institutions upon getting the consent from the principal/ head teacher of the concerned institution. The questionnaire were distributed to the students and the process was carried out taking each question from the questionnaire, explaining the significance/queries/examples related to each question and finally asking the students to mark their responses. A total of 240 students were randomly selected across three major groups (school children, graduates, post graduates). Each group consisted of 80 students each. Data was collected from each group in 4 batches at 4 different sessions comprising 20 students each in each batch. Thus the entire data was collected in 12 batches at 12 different sessions comprising 20 students each in each batch. This mechanism was followed so as to minimize biased response rates and gain maximum personnel attention of the students. Each session extended to duration of maximum of one hour. 44 percent of the sample respondents were males. The age group of the respondents fell between 11 to 27 years.

\section{Statistical tools used}

Data obtained through the questionnaires were analyzed using SPSS software package (Version 12) in 95 percent confidence interval. Cronbach alpha method was used to test the reliability of the questionnaire. Descriptive statistics, factor analysis, chi-square test, Levene's test, $t$-test, KruskalWallis test, one way ANOVA, Mann-Whitney $U$ test, Tukey HSD test etc were used for interpreting the results.

\section{Result and discussion}

\subsection{Reliability statistics}

Cronbach alpha was used for measuring the reliability of the questionnaire. Malhotra (2004) stated that the coefficient varies from $0-1$.Value of 0.6 or less generally signifies unsatisfactory internal consistency reliability. Alpha coefficients below 0.6 are weak in reliability, $0.6-0.8$ is moderate strong and $0.8-1.0$ is very strong in reliability. For the questionnaire used in the study, the amount of Cronbach alpha coefficient was obtained as 0.781 .Hence it was concluded that the desired questionnaire enjoyed acceptable reliability level.

\subsection{Descriptive statistics}

The result of this study emphasized and supported the importance of packaging as an important element of marketing (Ampuero and Vila, 2006 ; Bone and France, 2001; Serralvo and Cardoso, 2010). It was found that packaging of chocolates were crucial in attracting young consumers. Milk chocolates were the first preference ( 82.1 percent) followed by white chocolates (10 percent) and then dark chocolates (7.9 percent). 64.2 percent of the respondents consumed atleast one bar of chocolate weekly followed by 15 percent on a daily basis. This goes well to show that chocolates were undoubtedly a part of their eating habits. It was also interesting to note that about 68 percent of the respondents had the habit of trying different brands of chocolate. 
This finding revealed that young consumers were not so particular about the choice of their chocolate brand rather they had the habit of experimenting new brands. However the younger minds were muddled with an answer when asked with the statement, 'an attractive package will have a good taste', with over 35 percent agreeing to it, 37 percent disagreeing to it and 28 percent in a position unable to make a decision. This is in contradiction to Cheskin's concept of 'sensation transference' (as cited in Louw and Kimber, 2010), making it only partially valid. Consumers were equally muddled with an answer when asked to rate 'an attractive packaging to high quality' with over 34 percent agreeing to it, 35 percent disagreeing and 31 percent unclear with a decision. However 71 percent of the respondents associated an attractive chocolate package to be highly expensive.

An interesting observation worth noting was, among 72 percent who purchased a newly launched chocolate bar based on an attractive pack, 61 percent regretted having purchased it. These findings clearly portrayed that consumers were mislead by good looking chocolate packages. 8 percent of the consumers also had the opinion that the nutritional information and nutritional claims printed on chocolate packages were misleading. However this did not prevent them from trying out different brands of chocolates bars. Very less respondents complained ( 8 percent) or gave feedback ( 7 percent) to the manufacturer after consuming a chocolate bar. Out of the few who gave feedback or registered complaint, the major mode of complaint was through email ( 5 percent) followed by toll free number ( 2 percent) .It was also inferred that a strong chocolate package alone was not the prime motivator of purchase. As many as 46 percent of the respondents disagreed that a good packaging alone can sell the product, with over 19 percent of the respondents unable to make a comment and over 35 percent agreeing to it. But the respondents were confused with an answer when asked about their opinion, 'advertising alone can sell the product', with over 30 percent of the respondents unable to make an opinion, 38 percent agreeing to it and 32 percent disagreeing to it.46 percent of the respondents disagreed to the statement that a dual exposure of 'an unattractive pack with a strong advertisement' could sell the product with over 31 percent unable to make an opinion and only 23 percent agreeing to the statement. As high as 40 percent of the respondents were unable to make an opinion to the statement that a dual exposure of 'poor advertisement with a good attractive pack' could sell the product, with over 34 percent agreeing to it and 26 percent disagreeing to it. However it was concluded that a very strong advertisement with a very attractive pack together could sell the chocolate bar with over 94 percent of the respondents agreeing to it. As far as the environmental habits towards chocolate packages were considered, 51 percent of the respondents stated chocolate packages as environmental hazards with over 33 percent unable to give an opinion. But, even though the young consumers were aware of the disposal information (60 percent) given on chocolate packages, only 6 percent of the respondents followed it. This goes to show that not all the students possessed environmental friendly habits. This was the case with storage instructions given on chocolate packages. 96 percent of the students did not follow the storage instructions given on packages.

\subsection{Factor analysis}

To test the first objective, a factor analysis was carried out. Factor analysis is a technique used when the researcher is interested in identifying a smaller number of factors underlying a large number of observed variables. Variables that have a high correlation between them are largely independent of other subsets of variables, are combined into factors. A sample size of less than 100 is not very suitable for conducting factor analysis. A sample size above 500 is considered to be excellent. As a rule of thumb, a sample size of 200-300 is considered to be adequate for proper analysis (A.S. Gaur and S. S. Gaur, 2009).The present study had 240 respondents which were considered as adequate for factor analysis. The most important packaging factors (cues) that young consumers keep in mind before purchasing a newly launched chocolate bar where identified using factor analysis. The KaiserMeyer-Olkin value of 0.652 indicated that the patterns of correlation were relatively acceptable 
(Kaiser, 1974).Further, Bartlett's test of sphericity (Bartlett, 1950) was highly significant ( $\mathrm{P}=.000 ; \mathrm{p}$ $<0.001)$ and hence the factor analysis conducted was appropriate. The scree plot and the rotated component matrix with varimax rotation are as shown in Table 1 and Fig 1.

\section{Table 1}

Rotated Component Matrix

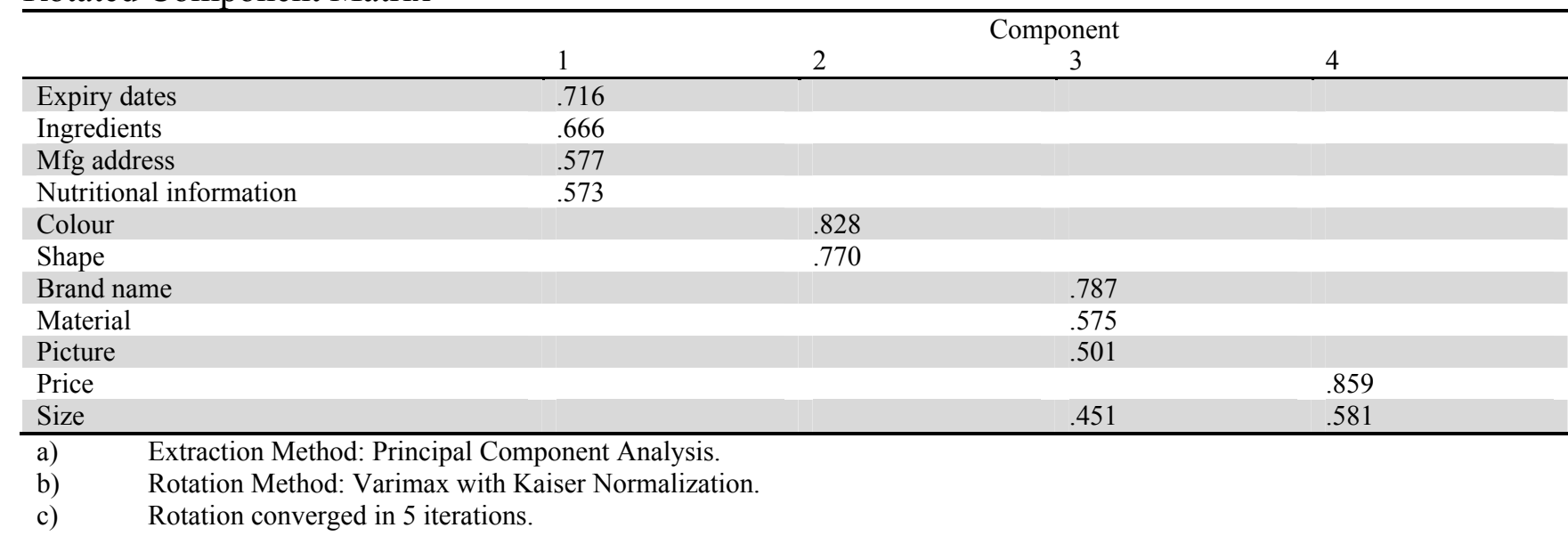

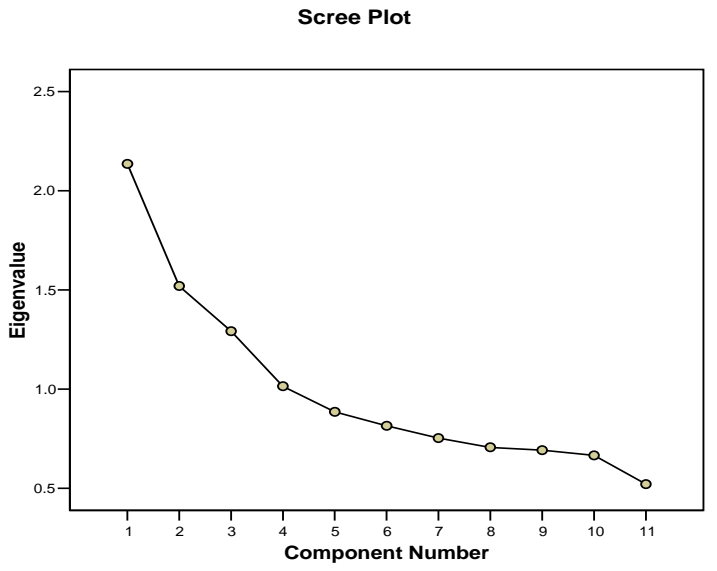

Fig. 1. Scree Plot

From Table 1 factor loadings less than 0.4 were suppressed and hence not shown. From the scree plot (Fig.1) and rotated component matrix (Table 1), only four factors with Eigen values greater than 1 converged and suggested a 4 factor solution. There was a sharp break in the sizes of Eigen values which resulted in a change in the slope of the plot from steep to shallow. It was observed that the slope of the scree plot changed from steep to shallow after the first two factors. The Eigen values also dropped from above 1.5 to less than 1 when moved from factor 4 to factor 5 . This suggested that a 4 factor solution may be the right choice. The obtained results from Table 1 showed that variables like 'expiry dates', 'ingredients', 'manufacturing address' and 'nutritional information' had the highest loadings at the first component and hence grouped under factor name 'Information'. Variables like 'colour' and 'shape' had the highest loadings at the second component and hence grouped under the factor name 'Appearance'. Variables named 'brand name', 'material' and 'picture' were having the highest loading at the third component and hence grouped together and named as 'Visual aesthetics'. Variables named 'price' and 'size' had the highest loadings at the fourth component and grouped under the factor name 'Outlook'.

\section{4 - test}

The grouped factors were further subjected to independent samples $t$ - test to further extract the most important factors which effect the consumers buying decision before going for the purchase of a 
newly launched chocolate bar. Gender of the respondent was taken as the grouping variable. Table 2 shows the details of the $t$ - test.

Table 2

Independent Samples Test

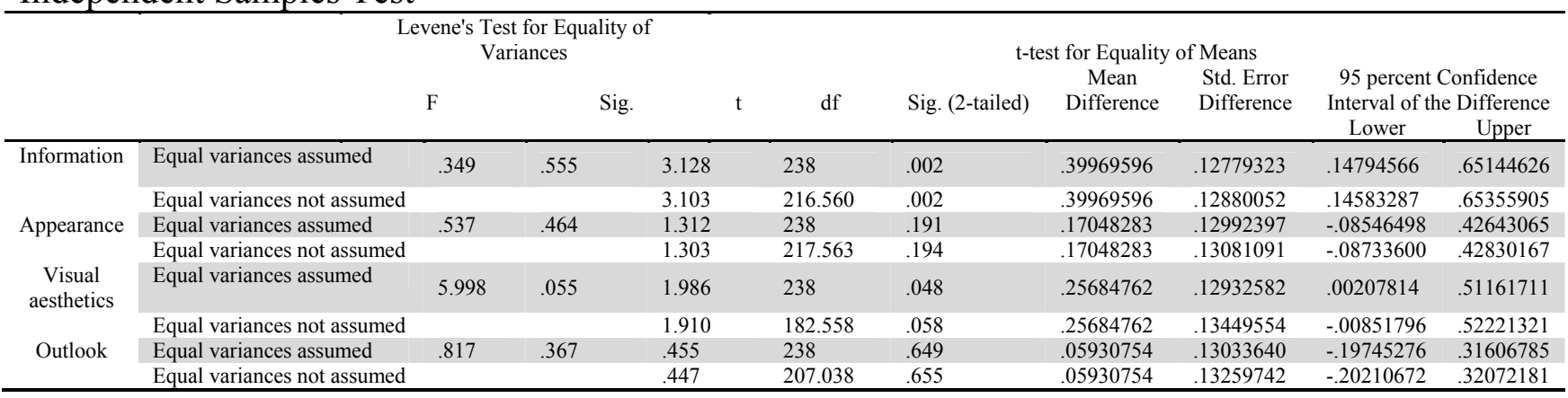

From Table 2, the significance level for Levene's test was above 0.05 for all the listed factors and hence equal variances were assumed. The observed $t$-values from Table 2 were 3.128 and 1.986 for factors 'Information' and 'Visual aesthetics' respectively. The two tailed probability of .002 (Information) and .048 (Visual aesthetics) were less than .05 and therefore the test was considered significant at .05 level of significance for these two factors only. Hence it is concluded that the most important factors which effect the consumers buying decision before going for the purchase of a newly launched chocolate bar are 'Information' and 'Visual aesthetics' thus making the null hypothesis 1 only partially valid.

\subsection{Chi-square test of independence}

To ascertain if there were any significant differences in gender as far as chocolate and health benefits awareness were concerned; two separate hypotheses were further tested.

$\mathrm{H}_{0}$ : There was no significant relationship between gender and the awareness of the concept that eating a bar of chocolate before examination increased memory power.

Table 3

Chi-Square Tests

\begin{tabular}{|c|c|c|c|c|c|}
\hline & Value & $\mathrm{df}$ & $\begin{array}{l}\text { Asymp. Sig. (2- } \\
\text { sided) }\end{array}$ & $\begin{array}{l}\text { Exact Sig. (2- } \\
\text { sided) }\end{array}$ & $\begin{array}{c}\text { Exact Sig. (1- } \\
\text { sided) }\end{array}$ \\
\hline Pearson Chi-Square & $3.447(\mathrm{a})$ & 1 & .063 & & \\
\hline Continuity Correction(a) & 2.976 & 1 & .084 & & \\
\hline Likelihood Ratio & 3.467 & 1 & .063 & & \\
\hline Fisher's Exact Test & & & & .067 & .042 \\
\hline Linear-by-Linear Association & 3.433 & 1 & .064 & & \\
\hline $\mathrm{N}$ of Valid Cases & 240 & & & & \\
\hline
\end{tabular}

(a). 0 cells (.0 percent) have expected count less than 5 . The minimum expected count is 45.06 .

The computed value (Pearson Chi-Square) of probability of the test statistic ( $p=.063$ ) was found to be greater than the probability of the alpha error rate $(\mathrm{p}=.05)$.Hence the test was not significant at 95 percent confidence interval (See Table 3). Hence the hypothesis was accepted. Thus there was no significant relationship between gender and the awareness of the concept that eating a bar of chocolate before examination increased memory power.

$\mathrm{H}_{0}$ : There was no significant relationship between gender and the awareness of the concept that eating a small bar of dark chocolate every day keeps the cardiovascular system running well.

The computed value (Pearson Chi-Square) of probability of the test statistic $(p=.006)$ was found to be lesser than the probability of the alpha error rate $(p=.05)$.Hence the test was significant at 95 percent confidence interval (See Table 4). 
Table 4

Chi-Square Tests

\begin{tabular}{|c|c|c|c|c|c|}
\hline & Value & df & $\begin{array}{l}\text { Asymp. Sig. (2- } \\
\text { sided) }\end{array}$ & $\begin{array}{l}\text { Exact Sig. (2- } \\
\text { sided) }\end{array}$ & $\begin{array}{l}\text { Exact Sig. (1- } \\
\text { sided) }\end{array}$ \\
\hline Pearson Chi-Square & $7.525(\mathrm{a})$ & 1 & .006 & & \\
\hline Continuity Correction(a) & 6.809 & 1 & .009 & & \\
\hline Likelihood Ratio & 7.634 & 1 & .006 & & \\
\hline Fisher's Exact Test & & & & .007 & .004 \\
\hline Linear-by-Linear Association & 7.494 & 1 & .006 & & \\
\hline $\mathrm{N}$ of Valid Cases & 240 & & & & \\
\hline
\end{tabular}

(a). 0 cells (.0 percent) have expected count less than 5 . The minimum expected count is 40.25

Hence the hypothesis was rejected. Hence there was significant relationship difference between gender and the awareness of the concept that eating a small bar of dark chocolate every day keeps the cardiovascular system running well. To find out which group differed significantly, an eyeballing of the expected frequencies revealed that females response over scored males in the awareness of this phenomenon thus making a significant difference to the chi square results.

\subsection{One Way ANOVA}

Hypothesis 2 was tested by a one way ANOVA with age as the independent factor and yielded the following result as shown in Table 5.

Table 5

ANOVA

\begin{tabular}{|c|c|c|c|c|c|c|}
\hline & & Sum of & $\mathrm{df}$ & Mean Square & $\mathrm{F}$ & Sig. \\
\hline \multirow[t]{3}{*}{ Shape } & Between Groups & 6.319 & 3 & 2.106 & 1.379 & .250 \\
\hline & Within Groups & 360.414 & 236 & 1.527 & & \\
\hline & Total & 366.733 & 239 & & & \\
\hline \multirow[t]{3}{*}{ Colour } & Between Groups & 3.875 & 3 & 1.292 & .989 & .398 \\
\hline & Within Groups & 308.125 & 236 & 1.306 & & \\
\hline & Total & 312.000 & 239 & & & \\
\hline \multirow[t]{3}{*}{ Picture } & Between Groups & 2.325 & 3 & .775 & .653 & .582 \\
\hline & Within Groups & 280.171 & 236 & 1.187 & & \\
\hline & Total & 282.496 & 239 & & & \\
\hline \multirow[t]{3}{*}{ Size } & Between Groups & 1.624 & 3 & .541 & .464 & .708 \\
\hline & Within Groups & 275.372 & 236 & 1.167 & & \\
\hline & Total & 276.996 & 239 & & & \\
\hline \multirow[t]{3}{*}{ Brand name } & Between Groups & 1.503 & 3 & .501 & .601 & .615 \\
\hline & Within Groups & 196.747 & 236 & .834 & & \\
\hline & Total & 198.250 & 239 & & & \\
\hline \multirow[t]{3}{*}{ Price } & Between Groups & 5.310 & 3 & 1.770 & 1.718 & .164 \\
\hline & Within Groups & 243.153 & 236 & 1.030 & & \\
\hline & Total & 248.462 & 239 & & & \\
\hline \multirow[t]{3}{*}{ Expiry dates } & Between Groups & 4.120 & 3 & 1.373 & .769 & .513 \\
\hline & Within Groups & 421.730 & 236 & 1.787 & & \\
\hline & Total & 425.850 & 239 & & & \\
\hline \multirow[t]{3}{*}{ Nutritional information } & Between Groups & 6.700 & 3 & 2.233 & 1.743 & .159 \\
\hline & Within Groups & 302.296 & 236 & 1.281 & & \\
\hline & Total & 308.996 & 239 & & & \\
\hline \multirow[t]{3}{*}{ Mfg address } & Between Groups & 8.749 & 3 & 2.916 & 2.361 & .072 \\
\hline & Within Groups & 291.501 & 236 & 1.235 & & \\
\hline & Total & 300.250 & 239 & & & \\
\hline \multirow[t]{3}{*}{ Material } & Between Groups & 11.311 & 3 & 3.770 & 3.445 & .017 \\
\hline & Within Groups & 258.289 & 236 & 1.094 & & \\
\hline & Total & 269.600 & 239 & & & \\
\hline \multirow[t]{3}{*}{ Ingredients } & Between Groups & 13.667 & 3 & 4.556 & 3.548 & .015 \\
\hline & Within Groups & 302.983 & 236 & 1.284 & & \\
\hline & Total & 316.650 & 239 & & & \\
\hline
\end{tabular}

The $\mathrm{F}$ ratio from Table 5 was significant with $\mathrm{F}(3,236)=3.445 ; \mathrm{p}=0.017$ for 'materials' and $\mathrm{F}$ $(3,236)=3.548 ; p=.015$ for 'ingredients' thus making the null hypothesis 2 only partially valid. A 
post -hoc Tukey HSD test was further conducted to examine the group differences. It was inferred that the age groups which fell between $16-18$ and $11-15$ were significantly different $(\mathrm{p}=0.018)$ from each other as far as the factor 'material' was concerned. Age groups between 19-22 and 11-15 were significantly different $(\mathrm{p}=0.008)$ from each other as far as the factor 'ingredients' were concerned.

\subsection{Chi-square test of independence}

Hypothesis 3 was tested using Chi square test of independence. The computed value of probability of the test statistic $(\mathrm{p}=.693)$ was found to be greater than the probability of the alpha error rate $(p=.05)$.Hence the test was not significant at 95 percent confidence interval and hypothesis 3 was accepted (see Table 6 and Table 7). Hence it was concluded that the influence of packaging for repeated purchase of chocolate bars was independent of the gender.

\section{Table 6}

Packaging and subsequent purchase * Sex: Cross tabulation

\begin{tabular}{|c|c|c|c|c|}
\hline & & \multicolumn{2}{|c|}{ Sex } & \multirow[b]{2}{*}{ Total } \\
\hline & & Male & Female & \\
\hline \multirow{6}{*}{$\begin{array}{l}\text { Packaging and subsequent } \\
\text { purchase }\end{array}$} & Strongly agree & 8 & 13 & 21 \\
\hline & Agree & 40 & 50 & 90 \\
\hline & Neither agree/ disagree & 26 & 33 & 59 \\
\hline & Disagree & 23 & 34 & 57 \\
\hline & Strongly disagree & 8 & 5 & 13 \\
\hline & Total & 105 & 135 & 240 \\
\hline
\end{tabular}

\section{Table 7}

Chi-Square Tests

\begin{tabular}{lccc}
\hline & Value & df & Asymp. Sig. (2-sided) \\
\hline Pearson Chi-Square & $2.232(\mathrm{a})$ & 4 & .693 \\
Likelihood Ratio & 2.223 & 4 & .695 \\
Linear-by-Linear Association & .292 & 1 & .589 \\
N of Valid Cases & 240 & & \\
\hline
\end{tabular}

(a). 0 cells (.0 percent) have expected count less than 5. The minimum expected count is 5.69.

\subsection{Kruskal-Wallis Test}

Hypotheses 4 to 7 were tested using Kruskal-Wallis Test. The results of the analysis indicated that there was significant difference $\left(\chi_{2}(3, N=240)=10.861, p=.013\right)$ of the influence of packaging in the first purchase of chocolate bars of international brands as far as qualifications were concerned (hypothesis 6 only). The results of the tests are shown in Table 8 and Table 9.

\section{Table 8}

Test Statistics $(a, b)$

\begin{tabular}{lcc} 
& & Packaging and international brand \\
\hline Chi-Square & Packaging and national brand & 10.861 \\
df & 4.226 & 3 \\
Asymp. Sig. & 3 & .013 \\
\hline
\end{tabular}
(a). Kruskal Wallis Test
(b). Grouping Variable: Qualification

\section{Table 9}

Test Statistics $(\mathrm{a}, \mathrm{b})$

\begin{tabular}{lcc}
\hline & Packaging and national brand & Packaging and international brand \\
\hline Chi-Square & 6.641 & 4.269 \\
df & 3 & 3 \\
Asymp. Sig. & .084 & .234 \\
\hline
\end{tabular}

(a). Kruskal Wallis Test

(b). Grouping Variable: Age 
Thus hypotheses 4, 5 and 7 were accepted and hypothesis 6 was rejected. Since the overall test was significant for hypothesis 6 only, a post hoc pair wise comparison among the different groups (qualifications) was completed using Mann-Whitney $U$ test. For hypothesis 6, the Mann-Whitney $U$ test yielded significant difference between the groups higher secondary's and postgraduates with Mann-Whitney $U=1441.500 ; \mathrm{p}=.004$ and between the groups graduates and post graduates with Mann-Whitney $U=2480.000 ; \mathrm{p}=.009$. See Tables 10 to 13 .

Table 10

Ranks

\begin{tabular}{lllc}
\hline & Qualification & N & Mean Rank \\
\cline { 2 - 4 } Packaging and international brand & Higher secondary & 50 & 54.33 \\
& Post graduate & 80 & 72.48 \\
\cline { 2 - 4 } & Total & 130 & 5798.50 \\
\hline
\end{tabular}

Table 11

Test Statistics (a)

\begin{tabular}{lc}
\hline & Packaging and international brand \\
\hline Mann-Whitney U & 1441.500 \\
Wilcoxon W & 2716.500 \\
Z & -2.870 \\
Asymp. Sig. (2-tailed) & .004 \\
\hline
\end{tabular}

(a). Grouping Variable: Qualification

Table 12

Ranks

\begin{tabular}{llccc}
\hline & Qualification & N & Mean Rank & Sum of Ranks \\
\hline \multirow{2}{*}{$\begin{array}{l}\text { Packaging and international } \\
\text { brand }\end{array}$} & Graduate & 80 & 71.50 & 5720.00 \\
& Post graduate & 80 & 89.50 & 7160.00 \\
& Total & 160 & & \\
\hline
\end{tabular}

\section{Table 13}

Test Statistics (a)

\begin{tabular}{lc}
\hline & Packaging and international brand \\
\hline Mann-Whitney U & 2480.000 \\
Wilcoxon W & 5720.000 \\
Z & -2.630 \\
\hline Asymp. Sig. (2-tailed) & .009 \\
\hline
\end{tabular}

(a). Grouping Variable: Qualification

\section{Conclusion and Implications}

The paper presented an empirical approach to understand the important packaging cues influencing young consumers when they purchased/planned to purchase newly launched chocolate bars from the market. It was found that packaging of chocolates were crucial in attracting young consumers. The most important factors which affected the consumers buying decision before going for the purchase were 'Information' and 'Visual aesthetics'. Factor variables like 'material' and 'ingredients' were found to be significant for certain age groups. Age groups which fell between 16-18 and 11-15 were significantly different from each other as far as the factor variable 'material' was concerned. Age groups between 11-15 were found to be more influenced with the material of the chocolate package. Age groups between 19-22 and 11-15 were significantly different from each other as far as the factor variable 'ingredients' were concerned. Age groups between 19-22 were found to be more influenced with the ingredients of the chocolate package. As far as chocolate packaging and subsequent purchases were concerned, it was concluded that the influence of packaging for repeated purchase of chocolate bars was independent of the gender. Chocolate packaging was found to have less influence on repeated purchase. It was inferred that there was significant difference regarding the influence of 
packaging in the purchase of chocolate bars of international brands as far as qualification was concerned. The groups belonging to higher secondary students and postgraduates were more influenced by the packaging of international brands of chocolates as compared to the groups' graduates and post graduates. The result of this study thus emphasized and further supported the importance of packaging as an important element of marketing (Ampuero and Vila, 2006 ; Bone and France, 2001; Serralvo and Cardoso, 2010).

\section{Limitation and scope for future research}

The study was restricted in a district of Kerala and the sample size drawn was small. Future studies may be extended to a wider area with a bigger sample size. As chocolate is a type of product which is consumed irrespective to age groups, the study could even be extended to all age groups from infants to older people. Such an extended study would throw more light in understanding the significant differences across several demographic variables. The study can also be raveled to understand the difference in purchase pattern if any across young consumers of urban and rural areas. The study could even be extended to diverse products/brands and even on unbranded chocolates and the consumer behavior patterns can be interpreted with different methods of analysis such as discriminant analysis, cluster analysis and so on.

\section{References}

Ampuero, O., \& Vila, N. (2006). Consumer perceptions of product packaging. Journal of Consumer Marketing , 23 (2), 100-112.

Aziz, A., Kadir, A., Rahimah, N., \& Yacob, N. (2011). Importance of packaging in consumer purchasing decisions. Retrieved from http://mgv.mim.edu.my/MMR/9112/911205.Htm

Barber, N., Almanza, B. A., \& Donovan, J. R. (2006). Motivational factors of gender, income and age on selecting a bottle of wine. International Journal of Wine Marketing , 18 (3), 218-232.

Bartlett, M. S. (1950). Periodogram Analysis and Continuous Spectra. Biometrika , 37(1-2), 1-16.

Bassin, S. B. (1988). Packaging: A Key Element in Added Value. Journal of Food Distribution Research , 6-11.

Bone, P. F., \& France, K. R. (2001). Package Graphics and Consumer Product Beliefs. Journal of Business and Psychology, 15 (3), 467-489.

Demetris, V., \& Claudio, V. (2001). A Market Investigation of the Situational Environment. British Food Journal , 103 (4), 291-296.

Doherty, B., \& Tranchell, S. (2007). Radical Mainstreaming' of Fairtrade:The Case of The Day Chocolate Equal Opportunities. Equal Opportunities International , 26 (7), 693-711.

Estiri, M., Hasangholipour, T., Yazdani, H., Nejad, H. J., \& Rayej, H. (2010). Food Products Consumer Behaviors: Role of Packaging elements. Journal of Applied Sciences , 10 (7), 535-543.

Gaur, A. S., \& Gaur, S. S. (2009). Statistical methods for practice and research:A guide to data analysis using SPSS. New Delhi: Sage Publications India Pvt Ltd.

Giyahi, Y. (2012). An empirical study on the relationship of purchasing a chocolate based on its packaging. Management Science Letters (2), 833-844.

Kaiser, H. F. (1974). An index of factorial simplicity. Psychometrika , 39, 31-36.

Lo" fgren, M. (2008). Customer satisfaction in the first and second moments of truth. Journal of Product \& Brand Management , 17 (7), 463-474.

Louw, A., \& Kimber, M. (2010). The Power of Packaging. Retrieved from http://www.scribd.com/doc/47169810/The-power-of-packaging

Malhotra, N. K. (2004). Marketing Research: An Applied Orientation. New Jersey: Pearson Education Inc.

Nancarrow, C., Wright, L. T., \& Brace, I. (1998). Gaining competitive advantage from packaging and labelling in marketing communications. British Food Journal , 100 (2), 110-118. 
Patwardhan, M., Flora, P., \& Gupta, A. (2010). Identification of Secondary Factors that Influence Consumer's Buying Behavior for Soaps and Chocolates. The IUP Journal of Marketing Management, 9 (1/2), 55-72.

Raghubir, P., \& Greenleaf, E. A. (2006). Ratios in Proportion: What Should the Shape of the Package Be? Journal of Marketing , 70, 95-107.

Rettie, R., \& Brewer, C. (2000). The verbal and visual components of package design. The Journal of Product and Brand Management , 9 (1), 56-68.

Sehrawet, M., \& Kundu, S. C. (2007). Buying behaviour of rural and urban consumers in India: the impact of packaging. International Journal of Consumer Studies , 31, 630-638.

Serralvo, F. A., João, B. N., \& Cardoso, O. O. (2010). The packing as intervening factor on consumer decision making process. Review of business research , 10 (3), 225-229.

Sharma, B. N. (2008). New Consumer Products Branding, Packaging and branding. The Journal of Nepalese Business Studies , 5 (1), 16-23.

Silayoi, P., \& Speece, M. (2004). Packaging and purchase decisions: An exploratory study of the impact of involvement and time pressure. British Food Journal , 106 (8), 607-628.

Soroka. (2002). Fundamentals of Packaging Technology (3 ed.). Institute of Packaging Professionals.

Stewart, B. (1995). Packaging as an Effective Marketing Tool. Pira International,Survey .

Underwood, R. L. (2003). The communicative power of product packaging: Creating brand identity via lived and mediated experience. Journal of Marketing Theory and Practice , 11 (1), 62-76.

Underwood, R. L., Klein, N. M., \& Burke, R. R. (2001). Packaging communication: attentional effects of product imagery. Journal of Product \& Brand Management , 10 (7), 403-422.

Vazquez, D., Bruce, M., \& Studd, R. (2003). A case study exploring the packaging design management process within a UK food retailer. British Food Journal , 105 (9), 602-617.

Venter, K., Merwe, D. v., Beer, H. d., Bosman, M., \& Kempen, E. (2011). Consumers' perceptions of food packaging: an exploratory investigation in Potchefstroom, South Africa. International Journal of Consumer Studies , 35, 273-281.

Vreeland, C. (2000). Organic Chocolate Market Skyrockets. Candy Industry , 166 (10), 51-56. 